\title{
Identification and Characterization of Arbutus unedo L. Endophytic Bacteria Isolated from Wild and Cultivated Trees for the Biological Control of Phytophthora cinnamomi
}

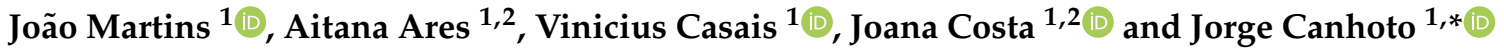 \\ 1 Department of Life Sciences, Centre for Functional Ecology, University of Coimbra, Calçada Martim \\ de Freitas, 3000-456 Coimbra, Portugal; joao.martins@uc.pt (J.M.); bioaitana26@gmail.com (A.A.); \\ viniciuscasais@gmail.com (V.C.); jcosta@uc.pt (J.C.) \\ 2 Laboratory for Phytopathology, Instituto Pedro Nunes, 3030-199 Coimbra, Portugal \\ * Correspondence: jorgecan@uc.pt
}

check for

updates

Citation: Martins, J.; Ares, A.; Casais, V.; Costa, J.; Canhoto, J. Identification and Characterization of Arbutus unedo L. Endophytic Bacteria Isolated from Wild and Cultivated Trees for the Biological Control of Phytophthora cinnamomi. Plants 2021, 10, 1569. https://doi.org/10.3390/ plants10081569

Academic Editor: Gabriella Cirvilleri

Received: 5 July 2021

Accepted: 28 July 2021

Published: 30 July 2021

Publisher's Note: MDPI stays neutral with regard to jurisdictional claims in published maps and institutional affiliations.

Copyright: (c) 2021 by the authors. Licensee MDPI, Basel, Switzerland. This article is an open access article distributed under the terms and conditions of the Creative Commons Attribution (CC BY) license (https:/ / creativecommons.org/licenses/by/ $4.0 /)$.

\begin{abstract}
Arbutus unedo L. is a resilient tree with a circum-Mediterranean distribution. Besides its ecological relevance, it is vital for local economies as a fruit tree. Several microorganisms are responsible for strawberry tree diseases, leading to production constrictions. Thus, the development of alternative plant protection strategies is necessary, such as bacterial endophytes, which may increase their host's overall fitness and productivity. As agricultural practices are a driving factor of microbiota, this paper aimed to isolate, identify and characterize endophytic bacteria from strawberry tree leaves from plants growing spontaneously in a natural environment as well as from plants growing in orchards. A total of 62 endophytes were isolated from leaves and identified as Bacillus, Paenibacillus, Pseudomonas, Sphingomonas and Staphylococcus. Although a slightly higher number of species was found in wild plants, no differences in terms of diversity indexes were found. Sixteen isolates were tested in vitro for their antagonistic effect against $A$. unedo mycopathogens. B. cereus was the most effective antagonist causing a growth reduction of $20 \%$ in Glomerella cingulata and $40 \%$ in Phytophthora cinnamomi and Mycosphaerella aurantia. Several endophytic isolates also exhibited plant growth-promoting potential. This study provides insights into the diversity of endophytic bacteria in $A$. unedo leaves and their potential role as growth promoters and pathogen antagonists.
\end{abstract}

Keywords: Arbutus unedo; Bacillus cereus; bacterial endophytes; biological control; Phytophthora cinnamomi

\section{Introduction}

Arbutus unedo L. is a small tree native in the Mediterranean basin as well as in Portugal and in South Ireland [1]. Commonly known as the strawberry tree, this member of the Ericaceae thrives on rocky marginal soils and dry lands and can tolerate a wide range of temperatures [2]. It is very important in southern European forest ecosystems, due to its ability to resprout after forest fires, a common scenario during the hot dry season. Besides avoiding erosion and desertification of extensive areas, it also prevents the colonization by invasive species [3]. Furthermore, it is very important from an economic point of view and its edible berries are the most important source of revenue for producers. Although they can be eaten raw, fruits are usually used in the production of a high-value alcoholic distillate [4]. The species is also a source of several bioactive compounds with application in the cosmetic and pharmaceutical industries [5]. Other applications are honey production and floriculture.

Due to the increasing demand for such products and a consequent market value growth, the production area has been rising considerably in recent years, although facing constraints due to phytosanitary problems. Several microorganisms, such as Glomerella cingulata [6], Mycosphaerella spp. [7] and Phytophthora cinnamomi [8], are known to be strawberry tree pathogens causing several diseases and leading to a reduction in plant fitness 
and constraints on crop production. The most aggressive is P. cinnamomi, an invasive and widespread oomycete, responsible for huge losses in agriculture and forestry worldwide, as it leads to tree decay [9], calling for adequate responses to improve agricultural practices and upkeep production.

To achieve this goal, a deep understanding of plant defence mechanisms is required as well as the selection and breeding of improved genotypes. Still, a change in paradigm is needed, and an integrative approach must be followed taking into consideration all the different aspects influencing plant performance and productivity. In this sense, the microbiota should be taken into account, as they have great significance in natural and agricultural ecosystems $[10,11]$. In particular, endophytic bacteria may confer advantages to host plants, promoting their overall fitness and productivity by enhancing plant resistance to biotic and abiotic stress conditions, such as pathogen attacks and drought [10]. These microorganisms are known to be the dominant group in these communities and have been isolated from numerous plant hosts where they live in symbiosis [12,13]. Such beneficial effects are accomplished through the production of phytohormones, secondary metabolites with important bioactive activities (e.g., antifungal and antiviral) and by promoting an increase of mineral uptake or nitrogen fixation $[12,13]$. Such features might be important in plant breeding and can be accomplished through the integration of specific endophytic bacteria genes on plants or by the inoculation of bacterial strains into the plant [10]. In addition, to enhance crop output, this approach can be a sustainable alternative for conventional pesticides and fertilizers, with economic and environmental benefits [14]. The structural characterization of plant microbiota, from their composition to the intricate interaction with the host plant, is essential for this knowledge to be applied by breeders and farmers [15]. Although the endophyte population dynamics have not yet been fully understood, several factors have been reported to cause variations among endophyte populations [13]. In particular, the surrounding environment and agricultural practices are considered the most crucial driving factors shaping the microbiota composition and functionality [16].

For this reason, the aim of this work was the isolation and molecular identification of endophytic bacteria from strawberry tree leaves from plants growing spontaneously in a natural environment as well as from plants growing in a production orchard, in order to compare the bacterial diversity between the two groups and evaluate the possible effects of agricultural practices on strawberry tree bacterial endophytes. Moreover, to assess the function of these bacterial endophytes in plant defence, its antagonism effect was tested against the most important strawberry tree pathogens, namely, Glomerella cingulata, Mycosphaerella aurantia and Phytophthora cinnamomi. Insights about the bacteria endophytic diversity and their plant growth-promoting features and antagonism effects are provided and the implications of these results on biological control strategies, plant phenotyping and breeding are discussed.

\section{Results}

\subsection{Isolation of Endophytic Bacteria from Cultivated and Wild Strawberry Trees}

A total of 62 endophytic strains were isolated from the leaves of strawberry tree. A similar number of isolates were obtained on the two media (ABM2 and 1/10 869) and three temperatures tested $\left(20,25\right.$ and $\left.30^{\circ} \mathrm{C}\right)$. In contrast, the number of isolates obtained greatly varied according to the medium $\mathrm{pH}(5.5,7.0$ and 8.5). A considerably higher number of isolates was obtained for $\mathrm{pH} 7$ on both mediums and no bacteria growth was observed on the ABM2 medium with pH 5.5 (Table S1).

From the 62 isolates, 32 were obtained from wild plants, whereas the other 29 from the cultivated ones. Random Amplified Polymorphic DNA (RAPD) profiles were obtained for all the 62 isolates and grouped in 50 different clusters. Most of the RAPD profiles (39) were unique. Eight clusters were formed by two isolates while the other three by three or more isolates. Isolates selected for $16 \mathrm{~S}$ rRNA gene amplification and sequencing were identified belonging to five genera (Bacillus, Paenibacillus, Pseudomonas, Sphingomonas and Staphylococcus) and 17 bacteria species (Figure 1, Table S2). 


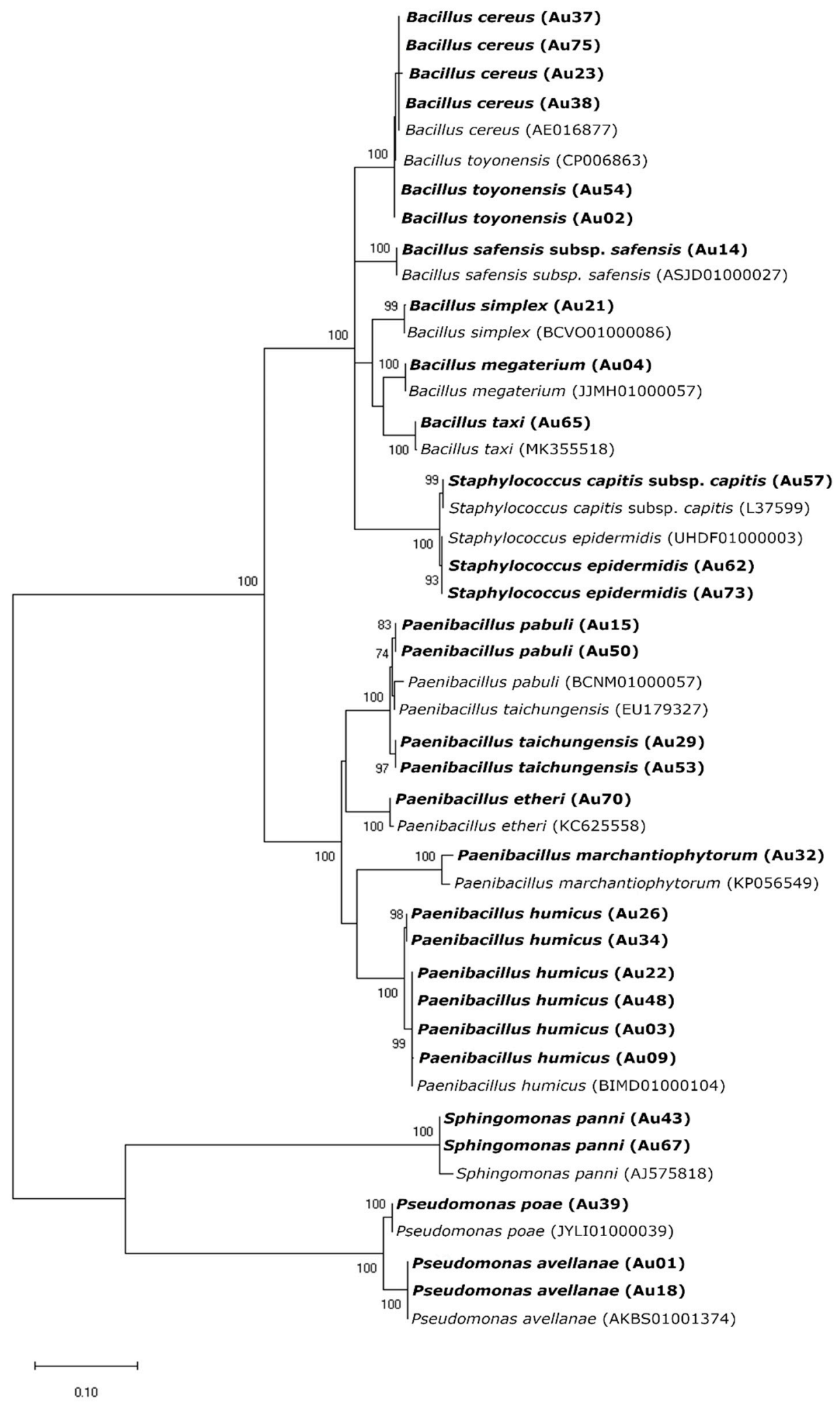

Figure 1. Maximum Likelihood (ML) phylogenetic tree based on 16S rRNA sequences of endophytic bacteria and sequences obtained from the EZBioCloud database. The ML tree was constructed using the Kimura 2 parameter model $(K 2)$ and gamma-distributed $(+G)$ with invariant sites $(+\mathrm{I})(=\mathrm{K} 2+\mathrm{G}+\mathrm{I})$. All positions containing gaps and missing data were included for analysis. Clade supports were calculated based on 1000 replicate runs. Accession numbers (GeneBank) of the sequences belonging to the endophytic bacteria isolated in this study and the reference sequences from EZBioCloud are listed in Table S2. 
A total of 21 distinct RAPD profiles were obtained from the bacterial isolates from cultivated plants, while 27 were obtained from strains isolated in wild plants (Figures 2a and 3). Only two RAPD profiles were common between isolates from cultivated and wild plants, identified as B. toyonensis and P. humicus. This difference was more marked in the number of species since seven different species were restricted to wild plants, while only four species were exclusively found in cultivated plants (Figures $2 \mathrm{~b}$ and 3). Additionally, five bacterial species were shared between wild and cultivated plants, namely, B. cereus, B. toyonensis, $P$. humicus, P. taichungensis and S. epidermidis. In terms of distribution between replicates, $P$. taichungensis was found on all the three replicates, from cultivated and isolated plants, whereas B. cereus was identified in all replicates from cultivated plants and P. humicus in wild plants (Figure 2c-d).
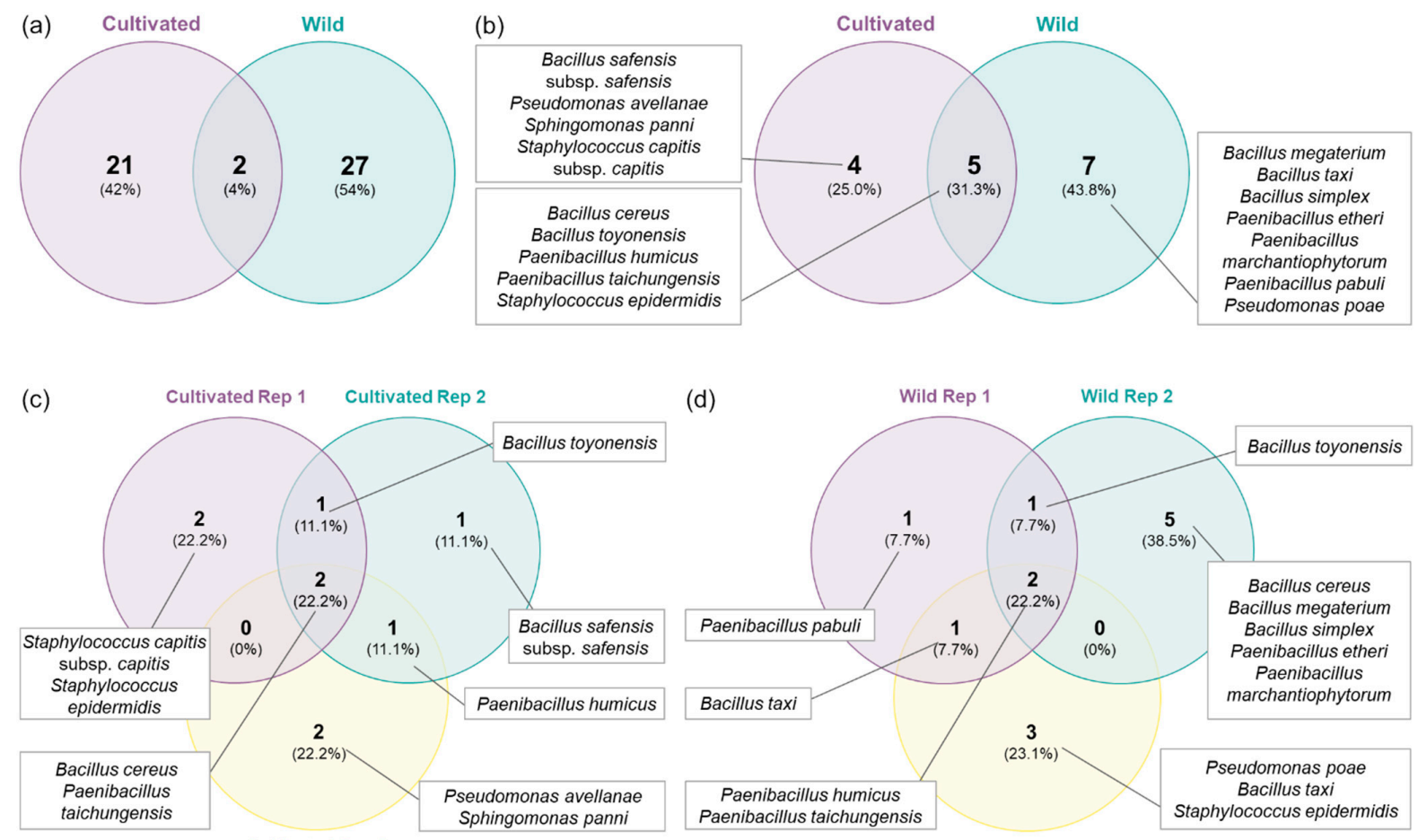

Figure 2. Venn diagrams with the number of RAPD profiles and bacteria species: (a) RAPD profiles from orchard and wild plants; (b) endophytic bacteria species from orchard and wild plants; (c) endophytic bacteria species from cultivated plant replicates; (d) endophytic bacteria species from wild plant replicates.

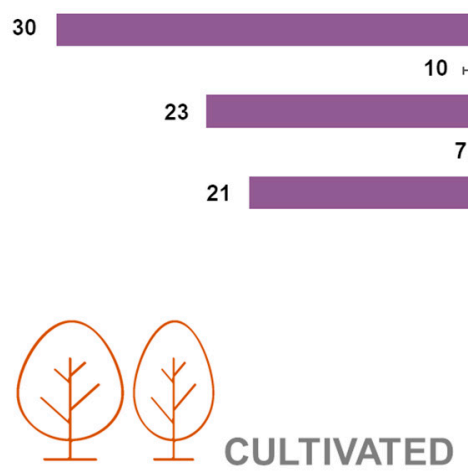

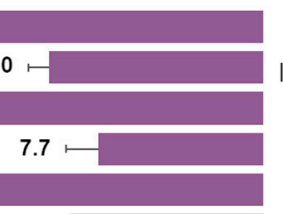

9

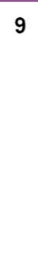

Isolates (total)

Isolates (average)

RAPD (total)

RAPD (average)

RAPD (unique)

Taxa (total)

Taxa (average)

Taxa (unique)

Simpson's (D)

Shannon (H')

Pielou (J')

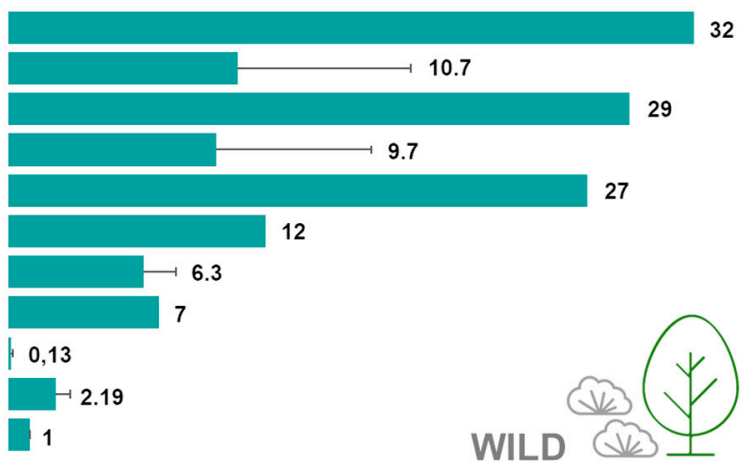

Figure 3. Number of isolates, RAPD profiles, taxa and diversity indexes (Simpson, Shannon and Pielou) of the endophytic bacterial isolates from cultivated and wild strawberry tree populations. 
Bacillus and Paenibacillus were the genera more often recovered, comprising 17 and 26 RAPD profiles, corresponding to 19 and 32 isolates, respectively. On the contrary, only two Pseudomonas species (P. avellanae in cultivated and P. poae in wild trees) were identified corresponding to three RAPD profiles with six isolates (Table S1). The same number of Staphylococcus species were identified (S. epidermidis and S. capitis), with three RAPD profiles and three isolates. Two isolates obtained from cultivated plants, with the same RAPD profile, were identified as Sphingomonas hankookensis, the only species found from this genus. Although seven species had only one RAPD profile, others had a considerably higher number of RAPD profiles: B. cereus (8), P. taichungensis (12) and P. humicus (15). Although the other endophytes isolated from strawberry tree leaves have already been identified in other plant species, as far as we know, this is the first report of Paenibacillus etheri as a plant endophyte (Table 1).

Table 1. Bacterial endophytes isolated from A. unedo and some plant species where these bacteria have been identified before.

\begin{tabular}{|c|c|}
\hline Bacteria Endophyte & Plant Species \\
\hline Bacillus cereus & $\begin{array}{l}\text { Teucrium polium and Sophora alopecuroides [17], Solanum lycopersicum [18], Polygonum cuspidatum [19], } \\
\text { Saccharum officinarum [20], Clitoria ternatea [21], Fragraria ananassa and Dyospiros kaki [22] }\end{array}$ \\
\hline B. megaterium & $\begin{array}{l}\text { Retama monosperma [23], Eucalyptus spp. [24], Gossypium hirsutum and Zea mays [25], S. lycopersicum } \\
\text { [18], S. officinarum [20] and V. radiata [26] }\end{array}$ \\
\hline B. nealsonii & Nicotiana attenuate [27] \\
\hline B. safensis & $\begin{array}{c}\text { Osmanthus fragrans [28], Musa sp. [29], P. cuspidatum [19], S. officinarum [20], Chloris virgata [30] and V. } \\
\text { radiata [26] }\end{array}$ \\
\hline B. simplex & P. cuspidatum [19] \\
\hline B. $\operatorname{taxi}$ & Taxus chinensis [31] \\
\hline B. toyonensis & S. lycopersicum [18] \\
\hline Paenibacillus etheri & - \\
\hline P. humicus & Acacia sp. [32] and Eucalyptus spp. [24] \\
\hline P. marcantiophytorum & Herbertus sendtneri [33] \\
\hline P. pabuli & P. cuspidatum [19], S. officinarum [20] and V. radiata [26] \\
\hline P. taichungensis & V. radiata $[26]$ \\
\hline P. poae & Vitis vinifera [34] \\
\hline Sphingomonas. panni & Musa sp. [29] \\
\hline $\begin{array}{l}\text { Staphylococcus capitis subsp. } \\
\text { capitis }\end{array}$ & G. hirsutum and Z. mays [25] \\
\hline S. epidermidis & S. lycopersicum [35] and Musa sp. [29] \\
\hline P. avellanae & Corylus avellane $[36,37]$ \\
\hline
\end{tabular}

The Simpson diversity index (D) calculated for both populations was $0.11 \pm 0.02$ for cultivated plants and $0.13 \pm 0.07$ for the wild ones, whereas the Shannon index $\left(\mathrm{H}^{\prime}\right)$ was $2.22 \pm 0.16$ in the cultivated group and $2.19 \pm 0.70$ in the wild one. Finally, Pielou's evenness index $\left(\mathrm{J}^{\prime}\right)$ was $1 \pm 0$ in the cultivated plants and $1 \pm 0$ in the wild population (Figure 3). No statistical differences were observed between groups for all the diversity indexes calculated.

\subsection{Antagonism Effect of Endophytic Bacteria against Plant Pathogens}

Sixteen strains were tested for the ability to inhibit the growth of strawberry tree pathogens. Although most of the isolates caused a reduction in the growth (inhibition) of Glomerella cingulata after one week in culture, this antagonism effect was reduced over time (Figure $4 \mathrm{a}-\mathrm{c}$ ). After 3 weeks in culture, the isolate Au06 (B. cereus) proved to be the most effective antagonist, causing a reduction in growth close to $30 \%$. Several of the tested bacterial isolates had the opposite effect, promoting the growth of G. cingulata (between 10\% and 30\%): Au3 (P. humicus), Au15 (P. pabuli), Au 21 (B. simplex), Au 47 (P. etheri), Au 53 (P. taichungensis) and Au 61 (B. taxi) (Figure 4c). 

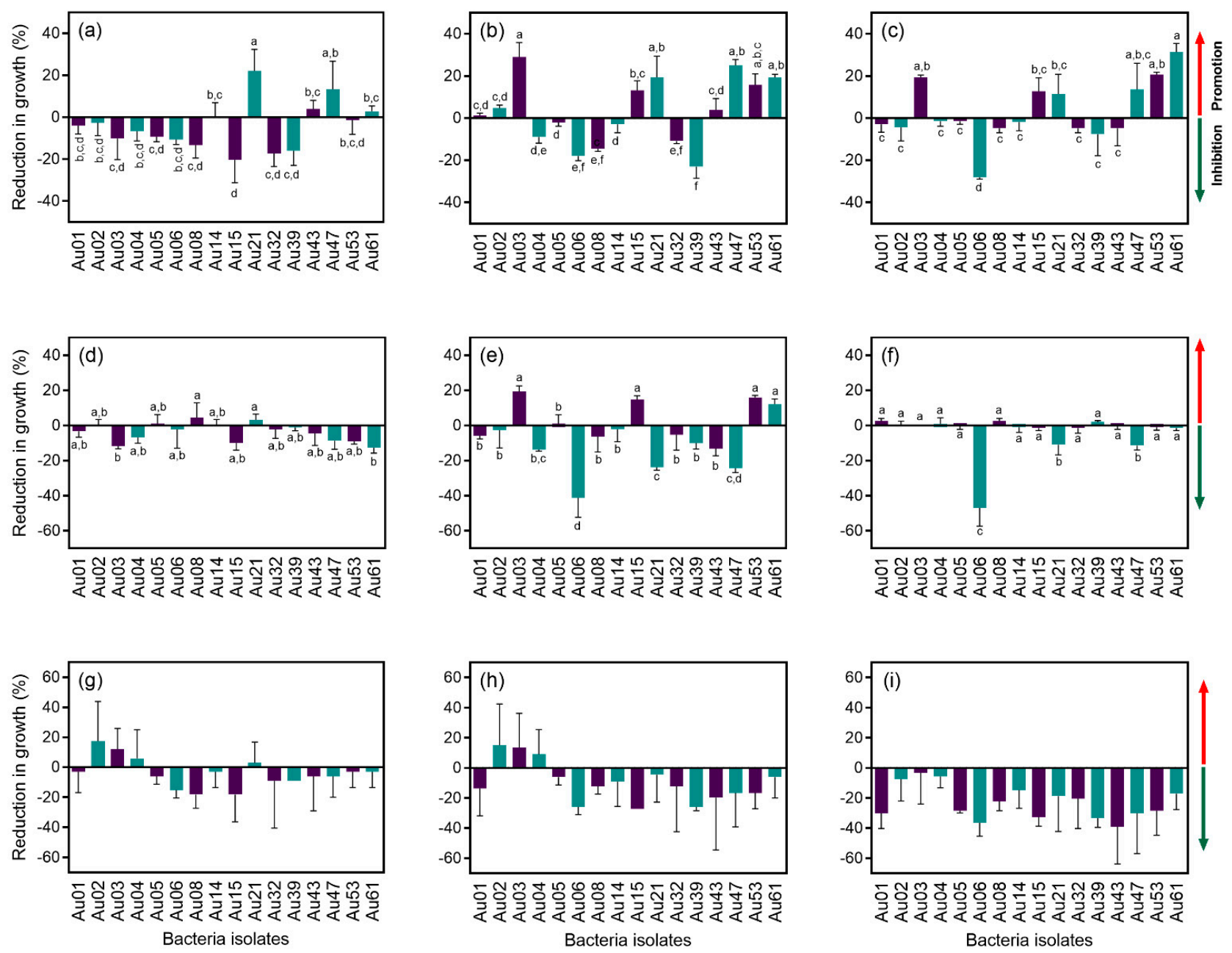

Figure 4. Antagonism assay between some of the endophytic bacteria isolated from Arbutus unedo and the plant pathogens Glomerella cingulata, Mycosphaerella aurantia and Phytophthora cinnamomi. Reduction in growth (\%) was calculated after 1, 2 and 3 weeks for G. cingulata and P. cinnamomi, and after 3, 6 and 9 weeks for M. aurantia. (a) G. cingulata after 1 week; (b) G. cingulata after 2 weeks; (c) G. cingulata after 3 weeks; (d) M. aurantia after 3 weeks; (e) M. aurantia after 6 weeks; (f) M. aurantia after 9 weeks; (g) P. cinnamomi after 1 week; (h) P. cinnamomi after 2 weeks; (i) Phytophthora cinnamomi after 3 weeks. Bacteria isolates: Au01-Pseudomonas avellanae; Au02_Bacillus toyonensis; Au03_Paenibacillus humicus; Au04—Bacillus megaterium; Au05-Bacillus toyonensis; Au06-Bacillus cereus; Au08—Bacillus toyonensis; Au14—Bacillus safensis; Au15-Paenibacillus pabuli; Au21-Bacillus simplex; Au32-Paenibacillus marchantiophytorum; Au39—Pseudomonas poae; Au43—Sphingomonas panni; Au47-Paenibacillus etheri; Au53-Paenibacillus taichungensis; and Au61-Bacillus taxi. Means \pm standard deviations, $n=3$; different letters indicate significant differences between treatments $(p \leq 0.05)$.

In the case of P. cinnamomi, a slight reduction in growth (less than $20 \%$ ) was observed after one week for most isolates (Figure 4d). This antagonist effect was intensified after two weeks (Figure 2e), but after three weeks in culture, the effect of the bacteria was barely noted, except for isolate Au06 (B. cereus), which caused a reduction in the growth of more than $40 \%$ (Figure $4 \mathrm{f}$ ).

Most of the bacterial isolates caused a reduction in the growth of $M$. aurantia after three and six weeks in culture (Figure $4 \mathrm{~g}$,h). After nine weeks, all the isolates proved to have an antagonist effect and caused a reduction in M. aurantia growth in some cases close to $40 \%$ (Figure $4 \mathrm{i}$ ).

Overall, B. cereus (Au06) was the most effective antagonist of $A$. unedo fungal pathogens tested in this study, as it was able to control their growth. It is important to note that the antagonism effect of $B$. cereus was caused at a distance and not by direct contact between microorganisms (Figure 5). 

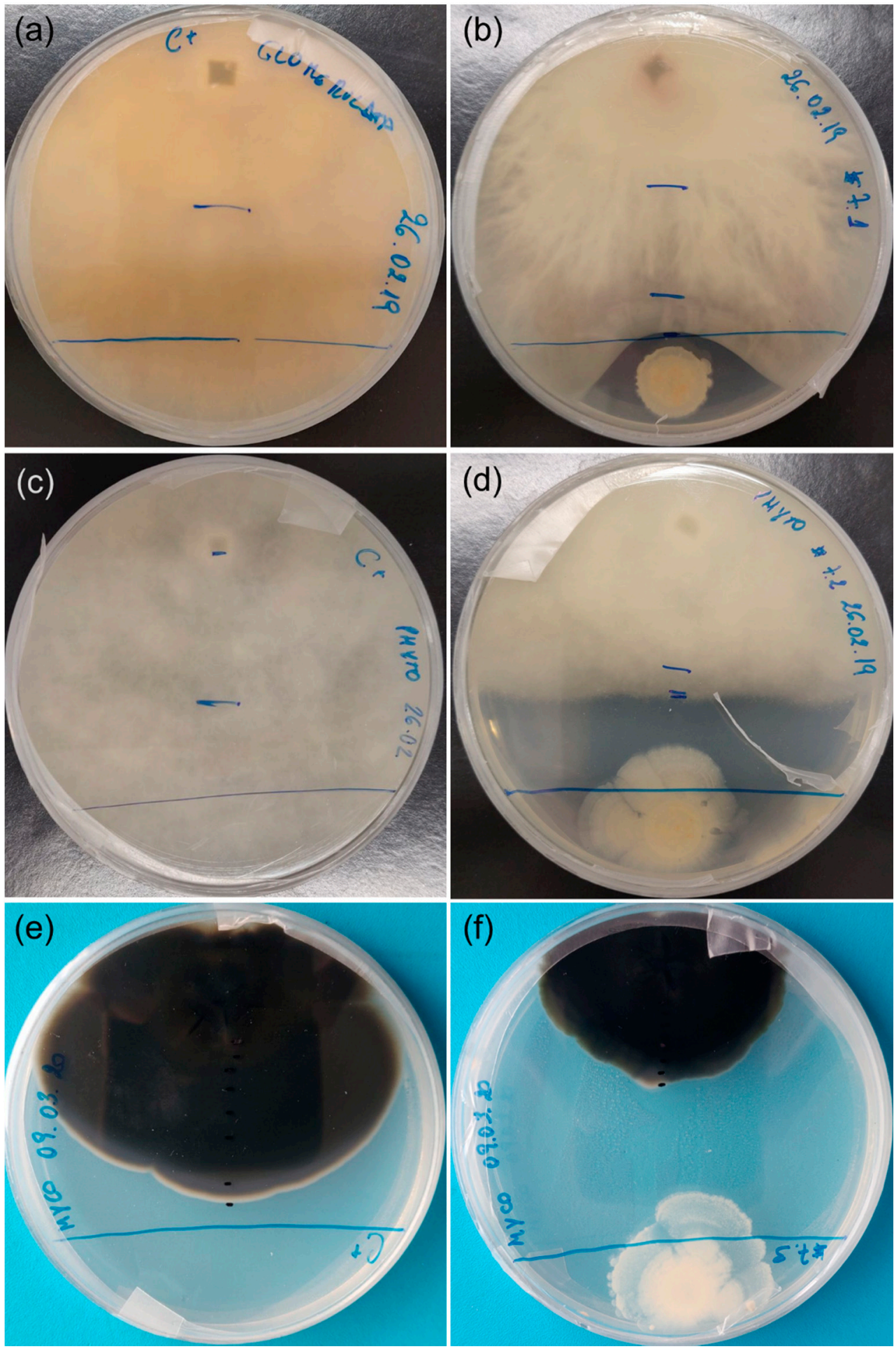

Figure 5. Antagonism test between Bacillus cereus (Au06) and Glomerella cingulata, Phytophthora cinnamomi and Mycosphaerella aurantia. (a) G. cingulata (3 weeks); (b) G. cingulata and B. cereus (3 weeks); (c) P. cinnamomi (3 weeks); (d) P. cinnamomi and B. cereus (3 weeks); (e) M. aurantia (9 weeks); (f) M. aurantia and B. cereus (9 weeks).

\subsection{Plant Growth-Promoting Potential of Endophytic Bacteria Isolated from Strawberry Tree}

From the 16 isolates tested, five were found to produce siderophores: Au01 (P. avellanae), Au06 (B. cereus), Au14 (B. safensis), Au39 (P. poae) and Au43 (S. panni); and four were able to solubilize phosphate: Au04 (B. megaterium), Au32 (P. marchantiophytorum), Au39 
(P. poae) and Au61 (Bacillus taxi) (Table 2). Whereas most of the isolates tested were able to produce ammonia, namely, Au01 (P. avellanae), Au02 (B. toyonensis), Au04 (B. megaterium), Au05 (B. toyonensis), Au06 (B. cereus), Au08 (B. toyonensis), Au14 (B. safensis), Au21 (B. simplex) and Au39 (P. poae) (Table 2), the production of IAA was only detected in six bacterial species: Au01 (P. avellanae), Au04 (B. megaterium), Au21 (B. simplex), Au39 (P. poae), Au43 (S. panni) and Au61 (B. taxi) (Table 2). IAA quantification revealed the production of this hormone by all the isolates, but considerable differences in the amount of IAA between the bacterial species were found, with values ranging from $0.56 \pm 0.43$ for isolate Au32 (P. marchantiophytorum) and $10.98 \pm 2.44$ produced for Au01 (P. avellanae) (Table 2).

Table 2. The growth-promoting potential of the isolated endophytic bacteria based on siderophore, ammonia and IAA production and phosphate solubilization. + indicates the production of IAA, siderophores and phosphate solubilization. Ammonia production: 0 -no production; 1 -low production; 2 -high production. IAA concentration values are the means \pm standard deviation of three independent replicates.

\begin{tabular}{|c|c|c|c|c|c|}
\hline Isolate & $\begin{array}{l}\text { Siderophores } \\
\text { Production }\end{array}$ & $\begin{array}{c}\text { Phosphate } \\
\text { Solubilization }\end{array}$ & $\begin{array}{l}\text { Ammonia } \\
\text { Production }\end{array}$ & $\begin{array}{c}\text { IAA } \\
\text { Production }\end{array}$ & IAA $\mu \mathrm{g} \mathrm{mL}^{-1}$ \\
\hline Au01 (Pseudomonas avellanae) & + & - & 2 & + & $10.98 \pm 2.44$ \\
\hline Au02 (Bacillus toyonensis) & - & - & 2 & - & $2.57 \pm 1.81$ \\
\hline Au03 (Paenibacillus humicus) & - & - & 0 & - & $1.90 \pm 1.81$ \\
\hline Au04 (Bacillus megaterium) & - & + & 2 & + & $6.22 \pm 4.69$ \\
\hline Au05 (Bacillus toyonensis) & - & - & 2 & - & $3.10 \pm 0.83$ \\
\hline Au06 (Bacillus cereus) & + & - & 2 & - & $1.72 \pm 1.75$ \\
\hline Au08 (Bacillus toyonensis) & - & - & 2 & - & $4.40 \pm 5.30$ \\
\hline Au14 (Bacillus safensis) & + & - & 2 & - & $2.21 \pm 0.59$ \\
\hline Au15 (Paenibacillus pabuli) & - & - & 0 & - & $3.07 \pm 1.42$ \\
\hline Au21 (Bacillus simplex) & - & - & 2 & + & $5.21 \pm 4.36$ \\
\hline $\begin{array}{l}\text { Au32 (Paenibacillus } \\
\text { marchantiophytorum) }\end{array}$ & - & + & 1 & - & $0.56 \pm 0.43$ \\
\hline Au39 (Pseudomonas poae) & + & + & 2 & + & $4.68 \pm 2.11$ \\
\hline Au43 (Sphingomonas panni) & + & - & 1 & + & $6.17 \pm 4.34$ \\
\hline Au47 (Paenibacillus etheri) & - & - & 0 & - & $0.74 \pm 0.03$ \\
\hline Au53 (Paenibacillus taichungensis) & - & - & 0 & - & $2.47 \pm 2.33$ \\
\hline Au61 (Bacillus taxi) & - & + & 0 & + & $3.87 \pm 1.76$ \\
\hline Control (Pseudomonas syringae) & + & - & 2 & + & $8.43 \pm 1.11$ \\
\hline Control (Escherichia coli) & & + & 2 & - & 0 \\
\hline Negative Control & - & - & 0 & - & 0 \\
\hline
\end{tabular}

\section{Discussion}

The two different media used in this study proved to be efficient for the isolation of strawberry tree endophytic bacteria. Although the ABM2 medium is more complex when compared to 869 , both had a common basal composition that was suitable for the recovery of bacteria. The difference observed in the number of isolates according to the $\mathrm{pH}$ of the medium was expected due to the influence of $\mathrm{pH}$ on shaping microbial communities. The higher number of isolates obtained at $\mathrm{pH} 7$ indicates that most strawberry tree culturable endophytic bacteria are neutrophiles.

A considerably higher number of RAPD profiles was obtained when compared to the number of species identified, which suggests a high inter-specific diversity. Another observation that reinforces this idea is the fact that no common RAPD profiles were found between replicates. The difference in the number of RAPD profiles and bacteria species between replicates on the cultivated plants suggests a more homogeneous microbiota within the population, whereas on the wild plants a higher heterogenicity seems to exist. Moreover, the total number of RAPD profiles as well as unique RAPD profiles were found to be higher in wild plants. The number of taxa identified in wild plants was also higher than in cultivated ones. Although these results suggest a higher diversity in the wild population when compared to the cultivated plants, diversity indexes were very similar 
between groups. Furthermore, Simpson and Pielou's indexes suggest low dominance of species and evenness among populations. As mentioned before, agricultural practices might have great influence on microbiota structure. Nitrogen fertilization, for example, a common practice in modern intensive agriculture, proved to lead to a decline in plant microbiota diversity in maize [38]. Moreover, either to promote growth and/or to facilitate fruit collection, orchard plants are pruned to obtain a specific plant architecture, which may also influence microbiota structure [11]. Although cultivated plants analysed in this study are regularly watered and pruned, and the soil fertilized, these practices do not seem to greatly affect microbiota diversity when compared to wild populations.

The surrounding environment is another important source of microorganisms that might be transmitted horizontally and enter the plant through different paths integrating its microbiota [16]. Thus, surrounding plants may constitute a local reservoir of bacteria, and as plant diversity is hypothetically lower in an agricultural ecosystem when compared to a wild forest, this could lead to a decrease in plant microbiota diversity. Due to the lack of such niches in the cultivated population studied, the horizontal transmission between individuals might be compromised, whereas the microbiota diversity in the wild population might be promoted due to the existence of several other plant species. Still, the contribution of these bacteria reservoirs on plant microbiota structure and transmission of dominant bacteria species needs to be further evaluated, as such knowledge can be used to improve agricultural practices (e.g., the inclusion of ecological corridors to promote local diversity).

Additionally, plant microbiota is also transmitted vertically by seeds or other propagation material. In this particular case, cultivated plants have been obtained by conventional seed germination. Thus, the origin of the seeds might be crucial to determine the microbiota composition of the plants. Nonetheless, future studies are required to evaluate the contribution of the propagation material to the plant core microbiome.

P. humicus was found on most replicate samples while P. taichungensis was found on all the samples both from wild and cultivated plants. Because these plants are under different conditions, this result might indicate these two bacteria species are part of the strawberry tree core microbiota, while the other species constitute the satellite microbiota. However, further studies with more plant genotypes growing in different environmental conditions are yet to be conducted to confirm this result.

A fierce competition for space and nutrient resources occur in microbial communities, including between bacteria and fungi, through different mechanisms such as cell signalling and antibiotic production. These complex interactions allow the coexistence or exclusion of some species [39]. In this work, several bacteria were able to antagonize fungal pathogens (G. cingulata and M. aurantia) and an oomycete (P. cinnamomi). The most promising results were obtained with B. cereus, which was able to antagonize the three plant pathogens tested. Its antifungal effect has already been reported in the literature against Fusarium oxysporum f. sp. lycopersici [18]. However, to our knowledge, this is the first report of its antifungal effect against G. cingulata, M. aurantia and P. cinnamomi. Several B. cereus strains were isolated from both populations (cultivated and wild), which seems to be an indicator of its importance and prevalence among strawberry tree populations. The antifungal effect of other bacteria, such as B. safensis, against other plant pathogens (Magnaporthe oryzae) has also been reported in the literature [28]. However, no antagonism effect of $B$. safensis was observed in this work on the pathogens tested.

Our characterization study also revealed the production of siderophores by five strawberry tree endophytic bacteria. The production of these low molecular weight compounds is an important competition mechanism, in particular under iron-limiting conditions [40]. Besides improving the nutritional status of bacteria, they also limit iron absorption by other organisms, such as fungi, which confers a competitive advantage and can be one of the mechanisms involved in biological control. Some of the isolates have also shown the ability to solubilize phosphate and produce ammonia, which are important bacterial features 
that enhances their nutritional status and have a significant effect on the competition with other microorganisms.

Bacteria might also produce IAA and other plant hormones. IAA production enhances microbial fitness as it stimulates cell wall loosening and nutrient leakage [39]. As one of the most important plant hormones, IAA is involved in several plant signalling pathways and greatly affects plant growth and development. Thus, the production of IAA by microorganism might be of great benefit to plants [41]. Although it is fairly known that most rhizobacteria can synthesize IAA, this is not the case for phyllosphere bacteria [42]. Nonetheless, our results revealed all the tested bacteria can produce IAA, even though in small quantities. For instance, the amount of IAA produced by B. cereus $\left(1.72 \mu \mathrm{g} \mathrm{mL}^{-1}\right)$ is much lower than that of $18 \mu \mathrm{g} \mathrm{mL}^{-1}$ quantified by Wagi and Ahmed [42]. This difference may be related to the experimental conditions (e.g., medium and temperature) or genetic factors. B. megaterium, B. safensis and P. pabuli have also been referred to in the literature as IAA-producing bacteria $[20,23]$.

This characterization study provides important insights about strawberry tree endophytic bacteria physiological mechanisms and possible ecological interactions with important implications in future biotechnological applications. Overall, endophytic bacteria have a great influence on plant resilience against biotic and abiotic stresses and a huge impact on plant health and development, leading to an increase in agricultural production. Plant microbiota contributes to a reduction in greenhouse gas emissions and chemical inputs mostly due to its benefits on plant nutrition (e.g., nitrogen fixation) and potential to reduce plant disease incidence $[11,16,43]$, leading to more sustainable agricultural practices. As pathogenic microorganisms are a chronic problem that affects food production, the dependency on agrochemicals is growing as agricultural production intensifies. Due to the negative impacts of agrochemicals (e.g., high cost, low efficiency, development of pathogen resistance and environmental impacts), a reduction in chemical inputs is a desirable goal for worldwide agriculture, making it urgent to develop alternative mitigation strategies. In this sense, biological control with bacteria can arise as an alternative, reliable crop protection method $[40,44]$. Furthermore, some bacteria species also have the potential for phytoremediation of contaminated soils [30].

Metabolomic studies, the identification of plant genes that are crucial for the microbial composition, as well as a better understanding of the microorganisms' physiology and multitrophic interactions should be pursued in the near future, as they are key factors to elucidate the recruiting mechanisms and interactions between bacteria and host plants. Such knowledge would have great repercussions on plant phenotyping and breeding and would allow further development of plant protection strategies and forest management strategies $[39,45]$. Due to its importance on plant phenotype, microbiome populations should be taken into account on plant selection. Moreover, propagation and plant breeding may lead to an interaction disruption between the plant and its microbiota [10]. Thus, the selection of plant genotypes with an appetence to establish symbiotic relations with specific bacteria species and/or strains might be of high importance to maintain these beneficial interactions [46].

\section{Materials and Methods}

\subsection{Collection of Plant Material}

Plant material was collected during May 2018 from 30 A. unedo trees growing in the wild (40.043334, -7.904996) and 30 in an orchard (40.029581, -7.924739), in Pampilhosa da Serra, Coimbra district, central Portugal. The distance between the groups is approximately $2 \mathrm{~km}$. Trees were $5 \mathrm{~m}$ apart on a $750 \mathrm{~m}^{2}$ area $(50 \mathrm{~m} \times 15 \mathrm{~m})$. Three replicates from each location were used, each replicate consisting of 10 healthy adult trees (i.e., without any disease symptoms). Five leaves without any visible symptoms were randomly collected from each tree (a total of 50 leaves per replicate) and pooled together (Figure 6). Leaves were stored in sterile plastic bags at $4{ }^{\circ} \mathrm{C}$ and processed within $24 \mathrm{~h}$. Plants from the wild location were growing under uncontrolled conditions, in a mixed forest with Pinus pinaster 
and shrubs (Erica arborea, Calluna vulgaris and Ulex spp.) as well as several weeds. In the orchard, an irrigation system was installed, plants were regularly pruned and fertilized, and the soil had been mobilized to remove weed species.
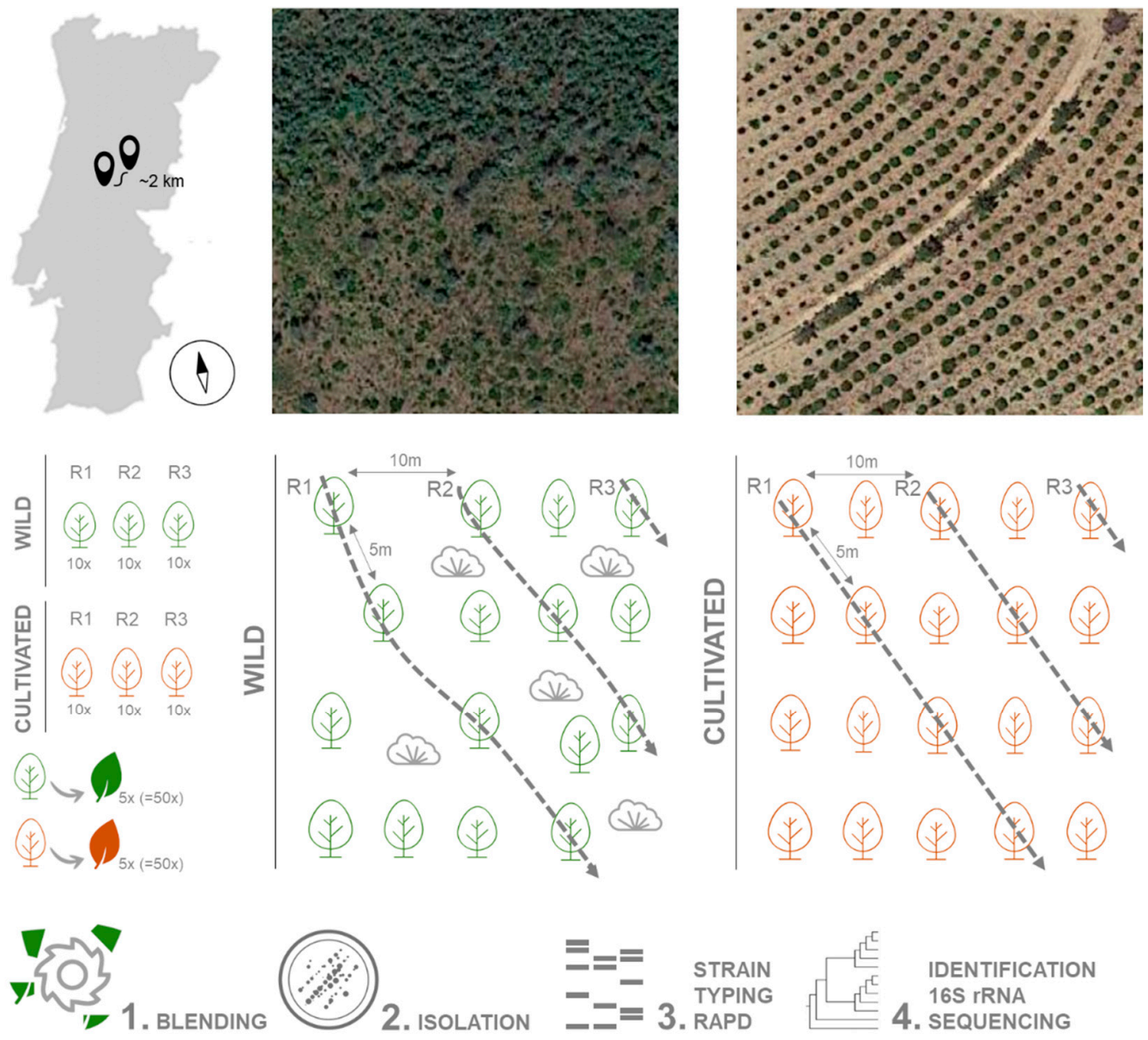

Figure 6. Strategies for sampling, isolation and identification of bacterial endophytes from strawberry tree leaves.

\subsection{Isolation of Endophytic Bacteria}

Leaves were sterilized as previously described by Eevers et al. [47]. Briefly, leaves were thoroughly washed in sterile ultra-pure water, surface-disinfected in ethanol $(70 \%, v / v)$ for $90 \mathrm{~s}$, sodium hypochlorite $(1 \%, w / v)$ for $3 \mathrm{~min}$ and finally rinsed five times in sterile ultra-pure water. The last rinsing water was inoculated in alkaline buffered medium 2 (ABM2 [48]) and incubated at $25{ }^{\circ} \mathrm{C}$ for $72 \mathrm{~h}$ to confirm the efficiency of the process. Approximately $10 \mathrm{~g}$ of sterilized leaves were shredded in a blender with $10 \mathrm{~mL}$ PBS buffer (10 mM, pH 7.2), and filtered through a sterile gauze cloth to remove plant debris. Several serial dilutions were prepared $(0,10-1,10-2,10-3,10-4)$ and $100 \mu \mathrm{L}$ of each dilution was inoculated in Petri dishes containing ABM2 and 1/10 869 medium [49], at pH 5.5, 7.0 and 8.5, and cultured at three different temperatures: 20,25 and $30^{\circ} \mathrm{C}$. Petri dishes were examined daily, and bacteria colonies were isolated in the same medium with the same $\mathrm{pH}$ and kept at $25^{\circ} \mathrm{C}$.

\subsection{Identification of Endophytic Bacteria}

\subsubsection{DNA Extraction and RAPD Fingerprint}

For DNA extraction, a crude lysate was prepared by resuspending a bacteria colony on $50 \mu \mathrm{L}$ of $0.5 \mathrm{M} \mathrm{NaOH}$, heated at $95^{\circ} \mathrm{C}$ for $4 \mathrm{~min}$ and immediately chilled on ice for $10 \mathrm{~min}$. 
After centrifugation at 10,000 $\mathrm{g}$ for $5 \mathrm{~min}$ to remove debris, the supernatant was collected and stored at $-20^{\circ} \mathrm{C}$ (adapted from Wiedmann-Al-Ahmad et al. [50]). RAPD-PCR was performed as previously described [51] to assess the genetic diversity of the bacterial strains using the primer OPA-03 (5'-AGTCAGCCAC-3'). PCR products were visualized on a $2 \%$ $(w / v)$ agarose gel stained with GreenSafe Premium (NZYTech, Oeiras, Portugal), under UV light. Clusters were formed by visual inspection based on the similarity and intensity of the fluorescence of each band observed in the RAPD profiles, namely, the number and weight of the bands when compared with each other and with the molecular weight marker. Strains from the same RAPD cluster were considered to be from the same species.

\subsubsection{Phylogenetic Analysis}

Phylogenetic analyses were performed in the representative bacterial strains selected from the previously established clusters based on the RAPD-PCR fingerprinting analysis (1-2 strains per cluster). Isolates were identified based on the 16S rRNA gene sequence (approximately $1500 \mathrm{bp}$ ) amplified by polymerase chain reaction (PCR) using primers 27F (5'-AGAGTTTGATCCTGGCTCAG-3') and 1525R (5'-GGTTACCTTGTTACGACTT-3') [52] PCR reactions contained $1 \times$ NZYTaq II $2 \times$ Colorless Master Mix (NZYTech), $10 \mathrm{mM}$ primer, $50 \mathrm{ng}$ DNA in a final reaction volume of $50 \mu \mathrm{L}$. The reactions were performed in a T100 ${ }^{\mathrm{TM}}$ Thermal Cycler (BioRad, Hercules, CA, USA) under the following conditions: $95{ }^{\circ} \mathrm{C}$ for $5 \mathrm{~min}$, followed by 30 cycles at $95^{\circ} \mathrm{C}$ for $1 \mathrm{~min}$, annealing at $55^{\circ} \mathrm{C}$ for $1 \mathrm{~min}$ and extension at $72{ }^{\circ} \mathrm{C}$ for $2 \mathrm{~min}$, before a final extension at $72{ }^{\circ} \mathrm{C}$ for $10 \mathrm{~min}$. PCR products were visualized on a $1.5 \%(w / v)$ agarose gel stained with GreenSafe Premium (NZYTech), under UV light. PCR products were purified and sequenced by StabVida (Oeiras, Portugal), using the reverse 519R primer (5'-GWATTACCGCGGCKGCTG-3') [53] to obtain a partial sequence. Sequences were manually edited using Sequence Scanner Software 2 (Applied Biosystems, Foster City, CA, USA) and compared with the available data from the EZBioCloud databases version 2020.10.12 [54]. Those obtained from EZBioCloud with more than $97 \%$ similarity with our isolates were used for phylogenetic analysis and aligned using ClustalW [55] within MEGA (version 10.0 for Windows; [56]). This operation was done for each bacterial genus separately. Best suitable DNA substitution models were assessed using the "find best DNA/Protein Models (ML)" function on MEGA by implementing the Maximum Likelihood (ML) statistical method to test the goodness of fit to several models of evolution. According to the estimated values of all parameters for each model, the best-fitting model to the dataset from the 16S rRNA gene sequences was Kimura 2-parameter (K2) and gamma-distributed (+G) with invariant sites (+I) (=K2+G+I) [57] for Bacillus spp. and Paenibacillus spp., Hasegawa-Kishino-Yano (HKY+G+I) [58] for Pseudomonas spp., Tamura 3-parameter (T92+G+I) [59] for Sphingomonas spp. and Tamura-Nei (TN93+G+I) [60] for Staphylococcus spp. Phylogenetic reconstruction was calculated using the Maximum Composite Likelihood method with bootstrap values calculated from 1000 replicate runs. To confirm the identification, a larger sequence was obtained from 30 representative isolates using the forward primers 357F (5'-CCTACGGGAGGCAGCAG$3^{\prime}$ ) [61] and 803F (5'-ATTAGATACCCTGGTAGTC-3') [53]. Similarly, sequences were compared with available data from EZBioCloud databases and a phylogenetic reconstruction was calculated using the Kimura 2-parameter model $(\mathrm{K} 2+\mathrm{G}+\mathrm{I})$ with the $16 \mathrm{~S}$ rRNA sequences obtained from the Arbutus unedo 30 representative bacteria isolates along with the most similar sequences retrieved from the EZBioCloud database (Table S2).

\subsection{Antagonism Ability of Bacterial Endophytes against A. unedo Fungal Pathogens}

Bacterial isolates were tested in vitro for their antagonistic effect against microorganisms (two fungi and one oomycete) known to be pathogenic to A. unedo, using the direct opposition method [62]. A strain randomly selected from each bacterial species from the genera Bacillus, Paenibacillus, Pseudomonas and Sphingomonas was used (a total of 16). Briefly, mycelia plugs with $5 \mathrm{~mm}$ taken from the outside ring of a 7-day-old actively growing colony of G. cingulata, M. aurantia and P. cinnamomi, from the Plant Biotechnology 
Laboratory collection (isolated from A. unedo), were placed at $1 \mathrm{~cm}$ from the wall of a Petri dish $\left(90 \mathrm{~mm}\right.$ ) with PDA medium (DifcoTM Potato Dextrose Agar: $4 \mathrm{gL}^{-1}$ potato starch, $20 \mathrm{gL}^{-1}$ dextrose, $15 \mathrm{gL}^{-1}$ agar). On the opposite side, $10 \mu \mathrm{L}$ of a bacteria inoculum $\left(1 \times 108 \mathrm{CFU} \mathrm{mL}{ }^{-1}\right)$ was placed. Plates were done in triplicate and incubated at room temperature. The reduction in the growth of G. cingulata and P. cinnamomi was calculated after 7, 14 and 21 days using the following formula: $R G=(T G-C G) / C G \times 100$ [63], where TG is the growth of the colony in dual cultures and CG is the growth of a control group. The reduction in the growth of $M$. aurantia was calculated after 3,6 and 9 weeks, as it is a slow-growing fungus.

\subsection{Plant Growth-Promoting Potential of Endophytic Bacteria}

Endophytic bacteria plant growth-promoting potential was tested on the same 16 isolates used on the antagonism assays. For this purpose, the siderophores production, phosphate solubilization, ammonia and indol-3-acetic-acid (IAA) production was tested.

\subsubsection{Siderophores Production}

Siderophore production was determined according to Almoneafy et al. [64]. Bacterial isolates were grown on LB broth $\left(10 \mathrm{gL}^{-1}\right.$ of peptone, $5 \mathrm{gL}^{-1}$ of yeast extract and $5 \mathrm{gL}^{-1}$ of $\mathrm{NaCl}$ ) for $24 \mathrm{~h}$. A $10 \mu \mathrm{L}$ drop of each culture was plated on LB medium (LB broth supplemented with $12 \mathrm{gL}^{-} 1$ agar) with chrome azurol S (CAS) complex [65] and incubated for 3 days at $28{ }^{\circ} \mathrm{C}$. The siderophore production was determined by the presence of an orange halo around the colony. Plates were done in triplicate.

\subsubsection{Phosphate Solubilization}

The ability of bacterial strains to solubilize phosphate was determined as previously described [64]. Briefly, isolates were grown for $24 \mathrm{~h}$ in GY medium $\left(10 \mathrm{~g} \mathrm{~L}^{-1}\right.$ glucose and $2 \mathrm{~g} \mathrm{~L}^{-1}$ yeast extract, supplemented after autoclaving with $50 \mathrm{~mL}$ of a $10 \% \mathrm{~K} 2 \mathrm{HPO} 4$ solution and $100 \mathrm{~mL}$ of a $10 \% \mathrm{CaCl} 2$ solution). A $10 \mu \mathrm{L}$ drop of the bacterial suspension was then plated in GYA medium (GY medium with $15 \mathrm{~g} \mathrm{~L}^{-1}$ agar) and incubated for 7 days at $28{ }^{\circ} \mathrm{C}$. The presence of a clear visible halo around colonies was indicative of phosphate solubilization by the bacterial isolate. Plates were done in triplicate.

\subsubsection{Ammonia Production}

The production of ammonia was tested as previously described by Singh and Yadav [66]. Briefly, bacterial isolates were inoculated in peptone water medium $\left(10 \mathrm{gL}^{-1}\right.$ of peptone and $5 \mathrm{gL}^{-1}$ of $\mathrm{NaCl}$ ) and incubated for 4 days at $30^{\circ} \mathrm{C}$. Nessler's reagent was added to the tubes and colour development from brown to yellow indicated ammonia production. The production level of ammonia was classified using a 0-2 scale: 0 indicating no production when no colour change was observed, 1 for low production when a faint yellow colour was observed, and 2 for high levels of ammonia production and clear development of the solution colour to yellow or brown. Tubes were done in triplicate.

\subsubsection{Indole-3-Acetic Acid Production}

The production of IAA was tested following a procedure previously described [64]. Briefly, isolates were cultured on LB medium supplemented with L-tryptophan $\left(40 \mu \mathrm{g} \mathrm{mL}^{-1}\right)$ and incubated for $48 \mathrm{~h}$ at $30^{\circ} \mathrm{C}$ and $160 \mathrm{rpm}$. After centrifugation at $10,000 \times \mathrm{g}$ for $15 \mathrm{~min}$, $1 \mathrm{~mL}$ of the filtrate culture and $1 \mathrm{~mL}$ of Salkowski's reagent $(1.5 \mathrm{~mL}$ of FeCl3.6H2O $0.5 \mathrm{M}$ solution, in $80 \mathrm{~mL}$ of $60 \%(v / v) \mathrm{H} 2 \mathrm{SO} 4)$ were mixed and incubated at room temperature for $30 \mathrm{~min}$. The presence of pink colour indicates the presence of IAA. The concentration of IAA produced by each bacterial isolate was colourimetrically quantified at $530 \mathrm{~nm}$ using an IAA standard curve $(0-25 \mu \mathrm{g} \mathrm{mL}-1, \mathrm{y}=0.0359 \mathrm{x}-0.0349, \mathrm{R} 2=0.995)$. Tests were done in triplicate. 


\subsection{Statistical Analysis}

Venn diagrams of the RAPD profiles and bacteria species from cropped and wild plants were constructed in R software version 4.0.3 [67], using the package VennDiagram [68]. The Shannon index $\left(\mathrm{H}^{\prime}\right)$, Simpson (D), Simpson reciprocal index (1-D') and Pielou index $\left(\mathrm{J}^{\prime}\right)$ were obtained to compare the diversity between populations. Diversity indexes were compared by a t-student test, whereas antagonism and IAA production data were analysed by one-way ANOVA using GraphPad Prism (v. 8.4.3 for Windows, San Diego, CA, USA), followed by a Tukey's multiple comparison test $(p<0.05)$.

\section{Conclusions}

Due to the economic potential and ecological importance of $A$. unedo in the Mediterranean region, knowledge about this plant's tolerance mechanisms against biotic and abiotic stress must be considerably improved, and plant protection strategies should be planned to ameliorate plant fitness. This study is the first step towards enhancing our understanding of the microbiota of $A$. unedo and provides the first identification and characterization of its endophytic culturable bacteria. Although a slightly higher number of taxa and RAPD profiles was identified in the wild population when compared to the cultivated plants, no differences were obtained in terms of diversity indexes, which seems to indicate that, in this specific case, microbiota diversity is not compromised by agricultural practices. Among the several species isolated and identified, a Bacillus cereus strain (Au06) proved its efficiency by antagonizing three plant pathogens, Glomerella cingulata, Phytophthora cinnamomi and Mycosphaerella aurantia, revealing its ecological importance and potential as a biological control agent. However, this research has raised many questions in need of further investigation, such as the contribution of horizontal and vertical transmission of microorganisms into strawberry trees. The non-culturable microbiome is currently under investigation and future research will explore the potential of B. cereus (Au06) as a biocontrol agent.

Supplementary Materials: The following are available online at https://www.mdpi.com/article/ 10.3390/plants10081569/s1, Table S1: Isolation conditions and identification of A. unedo bacteria isolates, Table S2: Identification of endophyte bacteria isolates by $16 \mathrm{~S}$ rRNA gene sequencing.

Author Contributions: Conceptualization, J.M. and J.C. (Jorge Canhoto); formal analysis, J.M., A.A. and V.C.; data analysis, J.M. and A.A.; writing-original draft preparation, J.M.; writing-review and editing, A.A., J.C. (Jorge Canhoto) and J.C. (Joana Costa); supervision, J.C. (Jorge Canhoto) and J.C. (Joana Costa); funding acquisition, J.C. (Jorge Canhoto) and J.C. (Joana Costa). All authors have read and agreed to the published version of the manuscript.

Funding: This research was funded by Foundation for Science and Technology (Portugal) who supported J. Martins PhD fellowship (SFRH/BD/122478/2016). The authors also acknowledge ReNATURE project (CENTRO-01-0145-FEDER-000007) and F4F-Forest for the future (CENTRO-085864-FSE-000031, Programa Operacional Regional do Centro, Fundo Social Europeu). This work was carried out at the R\&D Unit Center for Functional Ecology - Science for People and the Planet (CFE), with reference UIDB/04004/2020, financed by FCT/MCTES through national funds (PIDDAC). This work was made in the scope of CULTIVAR project (CENTRO-01-0145-FEDER-000020), co-financed by the Regional Operational Programme Centro 2020, Portugal 2020, and the European Union, through the European Fund for Regional Development (ERDF).

Data Availability Statement: Sequence data is available at https://www.ncbi.nlm.nih.gov/ (accessed on 27 July 2021), with accessions numbers MW534840 to MW534869.

Conflicts of Interest: The authors declare no conflict of interest. The funders had no role in the design of the study; in the collection, analyses, or interpretation of data; in the writing of the manuscript, or in the decision to publish the results. 


\section{References}

1. Torres, J.A.; Valle, F.; Pinto, C.; García-Fuentes, A.; Salazar, C.; Cano, E. Arbutus unedo L. communities in southern Iberian Peninsula mountains. Plant Ecol. 2002, 160, 207-223. [CrossRef]

2. Martins, J.; Monteiro, P.; Pinto, G.; Canhoto, J. Hybridization assays in strawberry tree toward the identification of plants displaying increased drought tolerance. Forests 2021, 12, 148. [CrossRef]

3. Martins, J.F.; Correia, S.I.; Canhoto, J.M. Somatic embryogenesis induction and plant regeneration in strawberry tree (Arbutus unedo L.). In Methods in Molecular Biology; Germana, M., Lambardi, M., Eds.; Humana Press: New York, NY, USA, 2016; Volume 1359, pp. 329-339.

4. Martins, J.F.; Santos, T.; Correia, S.I.; Canhoto, J.M. Somatic embryogenesis in Arbutus unedo L. and other Ericaceae. In Vegetative Propagation of Forest Trees; Park, Y.S., Bonga, J.M., Moon, H.K., Eds.; National Institute of Forest Science: Seoul, Korea, 2016; pp. 565-590.

5. Morgado, S.; Morgado, M.; Plácido, A.I.; Roque, F.; Duarte, A.P. Arbutus unedo L.: From traditional medicine to potential uses in modern pharmacotherapy. J. Ethnopharmacol. 2018, 225, 90-102. [CrossRef] [PubMed]

6. Polizzi, G.; Aiello, D.; Guarnaccia, V.; Vitale, A.; Perrone, G.; Stea, G. First report of damping-off on strawberry tree caused by Colletotrichum acutatum and C. simmondsii in Italy. Plant Dis. 2011, 95, 1588. [CrossRef] [PubMed]

7. Romero-Martin, M.A.; Trapero-Casas, A. La mancha foliar del madroño (Arbutus unedo) causada por Septoria unedonis var. vellanensis. Bol. Sanid. Veg. Plagas 2003, 29, 375-392.

8. Jung, T.; Pérez-Sierra, A.; Durán, A.; Jung, M.H.; Balci, Y.; Scanu, B. Canker and decline diseases caused by soil- and airborne Phytophthora species in forests and woodlands. Pers. Mol. Phylogeny Evol. Fungi 2018, 40, 182-220. [CrossRef]

9. Sena, K.; Crocker, E.; Vincelli, P.; Barton, C. Phytophthora cinnamomi as a driver of forest change: Implications for conservation and management. For. Ecol. Manag. 2018, 409, 799-807. [CrossRef]

10. Compant, S.; Samad, A.; Faist, H.; Sessitsch, A. A review on the plant microbiome: Ecology, functions, and emerging trends in microbial application. J. Adv. Res. 2019, 19, 29-37. [CrossRef]

11. Whipps, J.M.; Hand, P.; Pink, D.; Bending, G.D. Phyllosphere microbiology with special reference to diversity and plant genotype. J. Appl. Microbiol. 2008, 105, 1744-1755. [CrossRef]

12. Yang, R.; Liu, P.; Ye, W. Illumina-based analysis of endophytic bacterial diversity of tree peony (Paeonia Sect. Moutan) roots and leaves. Braz. J. Microbiol. 2017, 48, 695-705. [CrossRef]

13. Zinniel, D.K.; Lambrecht, P.; Harris, N.B.; Feng, Z.; Kuczmarski, D.; Higley, P.; Ishimaru, C.A.; Arunakumari, A.; Barletta, R.G.; Vidaver, A.K. Isolation and characterization of endophytic colonizing bacteria from agronomic crops and prairie plants. Appl. Environ. Microbiol. 2002, 68, 2198-2208. [CrossRef]

14. Rabiey, M.; Hailey, L.E.; Roy, S.R.; Grenz, K.; Al-Zadjali, M.A.S.; Barrett, G.A.; Jackson, R.W. Endophytes vs tree pathogens and pests: Can they be used as biological control agents to improve tree health? Eur. J. Plant Pathol. 2019, 155, 711-729. [CrossRef]

15. Toju, H.; Okayasu, K.; Notaguchi, M. Leaf-associated microbiomes of grafted tomato plants. Sci. Rep. 2019, 9, 1787. [CrossRef]

16. Wassermann, B.; Müller, H.; Berg, G. An apple a day: Which bacteria do we eat with organic and conventional apples? Front. Microbiol. 2019, 10, 1629. [CrossRef] [PubMed]

17. Lopes, R.; Tsui, S.; Gonçalves, P.J.R.O.; de Queiroz, M.V. A look into a multifunctional toolbox: Endophytic Bacillus species provide broad and underexploited benefits for plants. World J. Microbiol. Biotechnol. 2018, 34, 94. [CrossRef] [PubMed]

18. Rocha, F.Y.O.; de Oliveira, C.M.; da Silva, P.R.A.; de Melo, L.H.V.; do Carmo, M.G.F.; Baldani, J.I. Taxonomical and functional characterization of Bacillus strains isolated from tomato plants and their biocontrol activity against races 1, 2 and 3 of Fusarium oxysporum f. sp. Lycopersici. Appl. Soil Ecol. 2017, 120, 8-19. [CrossRef]

19. Sun, H.; He, Y.; Xiao, Q.; Ye, R.; Tian, Y. Isolation, characterization, and antimicrobial activity of endophytic bacteria from Polygonum cuspidatum. Afr. J. Microbiol. Res. 2013, 7, 1496-1504. [CrossRef]

20. Varma, P.K.; Kumar, K.V.K.; Sekhar, V.C.; Adilakshmi, D.; Suresh, M.; Kumar, N.R.; Jayachandra, K.; Anitha, R. Evaluation of endophytic bacteria for plant growth promotion and pathogen suppression traits in Saccharum officinarum. J. Agric. Sci. Technol. A 2017, 7, 537-545. [CrossRef]

21. Khaksar, G.; Treesubsuntorn, C.; Thiravetyan, P. Effect of endophytic Bacillus cereus ERBP inoculation into non-native host: Potentials and challenges for airborne formaldehyde removal. Plant Physiol. Biochem. 2016, 107, 326-336. [CrossRef]

22. Hu, H.J.; Chen, Y.L.; Wang, Y.F.; Tang, Y.Y.; Chen, S.L.; Yan, S.Z. Endophytic Bacillus cereus effectively controls Meloidogyne incognita on tomato plants through rapid rhizosphere occupation and repellent action. Plant Dis. 2017, 101, 448-455. [CrossRef]

23. Dahmani, M.A.; Desrut, A.; Moumen, B.; Verdon, J.; Mermouri, L.; Kacem, M.; Coutos-Thévenot, P.; Kaid-Harche, M.; Bergès, T.; Vriet, C. Unearthing the plant growth-promoting traits of Bacillus megaterium RmBm31, an endophytic bacterium isolated from root nodules of Retama monosperma. Front. Plant Sci. 2020, 11, 124. [CrossRef]

24. Ferreira, A.; Quecine, M.C.; Lacava, P.T.; Oda, S.; Azevedo, J.L.; Araújo, W.L. Diversity of endophytic bacteria from Eucalyptus species seeds and colonization of seedlings by Pantoea agglomerans. FEMS Microbiol. Lett. 2008, 287, 8-14. [CrossRef]

25. McInroy, J.A.; Kloepper, J.W. Survey of indigenous bacterial endophytes from cotton and sweet corn. Plant Soil 1995, 173, 337-342. [CrossRef]

26. Pandya, M.; Rajput, M.; Rajkumar, S. Exploring plant growth promoting potential of non rhizobial root nodules endophytes of Vigna radiata. Microbiology 2015, 84, 80-89. [CrossRef] 
27. Long, H.H.; Sonntag, D.G.; Schmidt, D.D.; Baldwin, I.T. The structure of the culturable root bacterial endophyte community of Nicotiana attenuata is organized by soil composition and host plant ethylene production and perception. New Phytol. 2010, 185, 554-567. [CrossRef] [PubMed]

28. Rong, S.; Xu, H.; Li, L.; Chen, R.; Gao, X.; Xu, Z. Antifungal activity of endophytic Bacillus safensis B21 and its potential application as a biopesticide to control rice blast. Pestic. Biochem. Physiol. 2020, 162, 69-77. [CrossRef]

29. Sekhar, A.C.; Thomas, P. Isolation and identification of shoot-Tip associated endophytic bacteria from Banana cv. Grand Naine and testing for antagonistic activity against Fusarium oxysporum f. sp. cubense. Am. J. Plant Sci. 2015, 6, 943-954. [CrossRef]

30. Wu, T.; Xu, J.; Liu, J.; Guo, W.H.; Li, X.B.; Xia, J.B.; Xie, W.J.; Yao, Z.G.; Zhang, Y.M.; Wang, R.Q. Characterization and initial application of endophytic Bacillus safensis strain ZY16 for improving phytoremediation of oil-contaminated saline soils. Front. Microbiol. 2019, 10, 991. [CrossRef] [PubMed]

31. Tuo, L.; Liu, F.; Yan, X.R.; Liu, Y. Bacillus taxi sp. nov., a novel endophytic bacterium isolated from root of Taxus chinensis (Pilger) Rehd. Int. J. Syst. Evol. Microbiol. 2020, 70, 481-486. [CrossRef]

32. Zineb, F.B.; Chahinez, M.; Abdelkader, B.; Sonia, S.; Odile, D.; Robin, D.; Antoine, G. Nodular bacterial endophyte diversity associated with native Acacia spp. in desert region of Algeria. Afr. J. Microbiol. Res. 2016, 10, 634-645. [CrossRef]

33. Guo, G.N.; Zhou, X.; Chen, Z.L.; Yang, Z.W.; Li, X.D.; Li, Y.H. Paenibacillus marchantiophytorum sp. nov., isolated from the liverwort Herbertus sendtneri. Int. J. Syst. Evol. Microbiol. 2016, 66, 755-761. [CrossRef] [PubMed]

34. Niem, J.M.; Billones-Baaijens, R.; Stodart, B.; Savocchia, S. Diversity profiling of grapevine microbial endosphere and antagonistic potential of endophytic Pseudomonas against grapevine trunk diseases. Front. Microbiol. 2020, 11, 477. [CrossRef]

35. Nawangsih, A.A.; Damayanti, I.; Wiyono, S.; Kartika, J.G. Selection and characterization of endophytic bacteria as biocontrol agents of tomato bacterial wilt disease. J. Biosci. 2011, 18, 66-70. [CrossRef]

36. Loreti, S.; Gallelli, A.; de Simone, D.; Bosco, A. Detection of Pseudomonas avellanae and the bacterial microflora of hazelnut affected by "Moria" in central Italy. J. Plant Pathol. 2009, 91, 365-373. [CrossRef]

37. Scortichini, M.; Natalini, E.; Marchesi, U. Evidence for separate origins of the two Pseudomonas avellanae lineages. Plant Pathol. 2006, 55, 451-457. [CrossRef]

38. Manching, H.C.; Balint-Kurti, P.J.; Stapleton, A.E. Southern leaf blight disease severity is correlated with decreased maize leaf epiphytic bacterial species richness and the phyllosphere bacterial diversity decline is enhanced by nitrogen fertilization. Front. Plant Sci. 2014, 5, 403. [CrossRef] [PubMed]

39. Vorholt, J.A. Microbial life in the phyllosphere. Nat. Rev. Microbiol. 2012, 10, 828-840. [CrossRef] [PubMed]

40. Compant, S.; Duffy, B.; Nowak, J.; Clément, C.; Barka, E.A. Use of plant growth-promoting bacteria for biocontrol of plant diseases: Principles, mechanisms of action, and future prospects. Appl. Environ. Microbiol. 2005, 71, 4951-4959. [CrossRef]

41. Zhao, Y. Auxin biosynthesis and its role in plant development. Annu. Rev. Plant Biol. 2010, 61, 49-64. [CrossRef]

42. Wagi, S.; Ahmed, A. Bacillus spp.: Potent microfactories of bacterial IAA. PeerJ 2019, 7, e7258. [CrossRef]

43. Turner, T.R.; James, E.K.; Poole, P.S. The plant microbiome. Genome Biol. 2013, 14, 209. [CrossRef] [PubMed]

44. Witzell, J.; Martín, J.A. Endophytes and forest health. In Endophytes of Forest Trees; Pirttila, A., Frank, A., Eds.; Springer International Publishing AG: New York, NY, USA, 2018; Volume 86, pp. 261-282.

45. Krabel, D.; Morgenstern, K.; Herzog, S. Endophytes in changing environments—Do we need new concepts in forest management? iForest 2013, 6, 112. [CrossRef]

46. Kubiak, K.; Wrzosek, M.; Przemieniecki, S.; Damszel, M.; Sierota, Z. Bacteria inhabiting wood of roots and stumps in forest and arable soils. In Endophytes of Forest Trees; Pirttila, A., Frank, A., Eds.; Springer International Publishing AG: New York, NY, USA, 2018; Volume 86, pp. 319-342.

47. Eevers, N.; Gielen, M.; Sánchez-López, A.; Jaspers, S.; White, J.C.; Vangronsveld, J.; Weyens, N. Optimization of isolation and cultivation of bacterial endophytes through addition of plant extract to nutrient media. Microb. Biotechnol. 2015, 8, 707-715. [CrossRef]

48. Tiago, I.; Chung, A.P.; Veríssimo, A. Bacterial diversity in a nonsaline alkaline environment: Heterotrophic aerobic populations. Appl. Environ. Microbiol. 2004, 70, 7378-7387. [CrossRef]

49. Mergeay, M.; Nies, D.; Schlegel, H.G.; Gerits, J.; Charles, P.; Van Gijsegem, F. Alcaligenes eutrophus CH34 is a facultative chemolithotroph with plasmid-bound resistance to heavy metals. J. Bacteriol. 1985, 162, 328-334. [CrossRef] [PubMed]

50. Wiedmann-Al-Ahmad, M.; Tichy, H.V.; Schon, G. Characterization of Acinetobacter type strains and isolates obtained from wastewater treatment plants by PCR fingerprinting. Appl. Environ. Microbiol. 1994, 60, 4066-4071. [CrossRef]

51. Costa, J.; Tiago, I.; Da Costa, M.S.; Veríssimo, A. Presence and persistence of Legionella spp. in groundwater. Appl. Environ. Microbiol. 2005, 71, 663-671. [CrossRef]

52. Rainey, F.A.; Ward-Rainey, N.; Kroppenstedt, R.M.; Stackebrandt, E. The genus Nocardiopsis represents a phylogenetically coherent taxon and a distinct actinomycete lineage: Proposal of Nocardiopsaceae fam. nov. Int. J. Syst. Bacteriol. 1996, 46, 1088-1092. [CrossRef]

53. Turner, S.; Pryer, K.M.; Miao, V.P.W.; Palmer, J.D. Investigating deep phylogenetic relationships among cyanobacteria and plastids by small subunit rRNA sequence analysis. J. Eukaryot. Microbiol. 1999, 46, 327-338. [CrossRef]

54. Yoon, S.H.; Ha, S.M.; Kwon, S.; Lim, J.; Kim, Y.; Seo, H.; Chun, J. Introducing EzBioCloud: A taxonomically united database of 16S rRNA gene sequences and whole-genome assemblies. Int. J. Syst. Evol. Microbiol. 2017, 67, 1613-1617. [CrossRef] 
55. Thompson, J.; Higgins, D.G.; Gibson, T.J. CLUSTAL W: Improving the sensitivity of progressive multiple sequence alignment through sequence weighting, position-specific gap penalties and weight matrix choice. Nucleic Acids Res. 1994, 22, 4673-4680. [CrossRef] [PubMed]

56. Kumar, S.; Stecher, G.; Li, M.; Knyaz, C.; Tamura, K. MEGA X: Molecular Evolutionary Genetics Analysis across Computing Platforms. Mol. Biol. Evol. 2018, 35, 1547-1549. [CrossRef]

57. Kimura, M. A simple method for estimating evolutionary rates of base substitutions through comparative studies of nucleotide sequences. J. Mol. Evol. 1980, 16, 111-120. [CrossRef] [PubMed]

58. Hasegawa, M.; Kishino, H.; Yano, T. Dating of the human-ape splitting by a molecular clock of mitochondrial DNA. J. Mol. Evol. 1985, 22, 160-174. [CrossRef]

59. Tamura, K. Estimation of the number of nucleotide substitutions when there are strong transition-transversion and $\mathrm{G}+\mathrm{C}-\mathrm{content}$ biases. Mol. Biol. Evol. 1992, 9, 678-687. [CrossRef]

60. Tamura, K.; Nei, M. Estimation of the number of nucleotide substitutions in the control region of mitochondrial DNA in humans and chimpanzees. Mol. Biol. Evol. 1993, 10, 512-526. [CrossRef] [PubMed]

61. Muyzer, G.; De Waal, E.C.; Uitterlinden, A.G. Profiling of complex microbial populations by denaturing gradient gel electrophoresis analysis of polymerase chain reaction-amplified genes coding for 16S rRNA. Appl. Environ. Microbiol. 1993, 59, 695-700. [CrossRef] [PubMed]

62. Dennis, C.; Webster, J. Antagonistic properties of species-groups of Trichoderma: III. Hyphal interaction. Trans. Br. Mycol. Soc. 1971, 57, 363-369. [CrossRef]

63. Lahlali, R.; Bajii, M.; Jijakli, M.H. Isolation and evaluation of bacteria and fungi as biological control agents against Rhizoctonia solani. Commun. Agric. Appl. Biol. Sci. 2007, 72, 973-982.

64. Almoneafy, A.A.; Xie, G.L.; Tian, W.X.; Xu, L.H.; Zhang, G.Q.; Ibrahim, M. Characterization and evaluation of Bacillus isolates for their potential plant growth and biocontrol activities against tomato bacterial wilt. Afr. J. Biotechnol. 2012, 11, 7193-7201. [CrossRef]

65. Schwyn, B.; Neilands, J.B. Universal chemical assay for the detection and determination of siderophores. Anal. Biochem. 1987, 160, 47-56. [CrossRef]

66. Singh, D.; Kumar Yadav, D. Potential of Bacillus amyloliquefaciens for biocontrol of bacterial wilt of tomato incited by Ralstonia solanacearum. J. Plant. Pathol. Microbiol. 2016, 7, 1-6. [CrossRef]

67. R Core Team. R: A Language and Environment for Statistical Computing; R Foundation for Statistical Computing: Vienna, Austria, 2020. Available online: https:/ / www.R-project.org/ (accessed on 1 July 2020).

68. Chen, H. VennDiagram: Generate High-Resolution Venn and Euler Plots. R Package Version 1.6.20. 2018. Available online: https:/ /CRAN.R-project.org/package=VennDiagram (accessed on 1 July 2020). 